\title{
Sen and Mead on Identity, Agency, and Economic Behavior
}

\section{Guido Baggio}

\section{(2) OpenEdition \\ 1 Journals}

Electronic version

URL: http://journals.openedition.org/ejpap/989

DOI: $10.4000 /$ ejpap.989

ISSN: 2036-4091

Publisher

Associazione Pragma

\section{Electronic reference}

Guido Baggio, «Sen and Mead on Identity, Agency, and Economic Behavior », European Journal of Pragmatism and American Philosophy [Online], IX-1 | 2017, Online since 22 July 2017, connection on 21 December 2020. URL : http://journals.openedition.org/ejpap/989 ; DOI : https://doi.org/10.4000/ ejpap.989

This text was automatically generated on 21 December 2020.

\section{c) (†) $९$}

Author retains copyright and grants the European Journal of Pragmatism and American Philosophy right of first publication with the work simultaneously licensed under a Creative Commons AttributionNonCommercial-NoDerivatives 4.0 International License. 


\title{
Sen and Mead on Identity, Agency, and Economic Behavior
}

\author{
Guido Baggio
}

\section{AUTHOR'S NOTE}

I thank the reviewers for their suggestions on an earlier version of this article.

\section{Introduction}

1 Through an exposition of the similarities between Mead's and Sen's ideas regarding the social constitution of the self, we see that, by discussing the nature of the behavioral foundation of economics, Sen tackled the problem of "identity" stressing that: "community, nationality, class, race, sex, union membership, the fellowship of oligopolist, revolutionary solidarity, and so on, provide identities that can be, depending on the context, crucial to ourselves" (Sen 1985: 348). A person's identities and concept of their own welfare can be influenced by one's identification with others. Persons' experiences in their proximity to others occur in relation to what Mead calls the "generalized other" namely, the: "organized community or social group which gives to the individual his unity of self" (Mead 1934: 154). The attitude of the "generalized other" is that of the whole community, that is, the common ethos which gives unity and consistency to the person's identities as well as person's relational resources combined with their abilities.

2 This paper is developed as follows. First, I expose the main characteristics of Sen's Capability Approach (CA) as an alternative to "welfarist" and 'utilitarian' approaches. I then point out the strict relation between CA and the way in which people elaborate their identities and how such identities condition the desires, interests, and preferences implied in evaluative processes. However, even if Sen develops a paradigm in which people's identities and values regarding the ways of living that they have 
reason to value are strictly intertwined with community identities and interests, I argue that a more specific in-depth analysis is needed to conceptualize how a person's identities, values, desires, and interests are likely to be constituted. In particular, a more specific in-depth analysis is required using a "disciplinary" net that meshes conceptual elements of philosophy, psychology (social and cognitive), and social and economic sciences. This net would be particularly valid for economics, I argue. In fact, the economic behaviors of human agents are part of general "human conduct" and represent in everyday life the manifestations of a person's - or as Mead calls it a self's identities generated in a community and strictly related to rule-based conduct.

3 I then introduce my main proposal, that a pragmatist approach, and in particular Mead's approach to human behavior, would pave the way for a new theoretical frame, a sort of 'paradigm' concerning human conduct, in which the various disciplines that concern the different components of self are functionally intertwined in a complex model of human conduct. Hence it is possible to identify some interesting connections between Sen's paradigm and Mead's social theory of the self that would implement "a pragmatist and institutionalist account of evaluation" (De Munck \& Zimmermann 2015: 132) from a transdisciplinary perspective aiming to address how valuable options are constituted and practical judgments formulated. ${ }^{1}$ A practical judgment or, as Sen calls it, an evaluative judgment, is the final phase of an act of evaluation about one's desired quotidian outcomes, means, and ends-in-view.

\section{The Capability Approach. An Alternative to Welfarist and Utilitarian Approaches}

4 The CA is not a theory; it is a "paradigm," namely a mode of thinking within which to conceptualize and evaluate phenomena that determine the ways of living that people value (Sen 1990a: 114, 2000: 74 and 2009: 231-2. See Robeyns 2005: 94-6). Persons' capabilities can be defined as what they are effectively able to do, that is, the effective opportunities they have to undertake the actions and activities that they wish to engage in, and be who they want to be.

5 It follows then that the CA provides a tool to be used to consider evaluative purposes, focusing upon the information needed in order to make judgments about individual well-being, and it is not reducible to alternative approaches such as, for example, an evaluation in monetary terms. In particular, it specifies an evaluative space as an alternative to other evaluative approaches, such as 'welfarist' and 'utilitarian' optics.

Welfarism - a special case of consequentialism - is the view that the moral character of society can be judged entirely upon information about the utility levels achieved by every human being in that society. It is, according to Sen (1979: 538): “a strong version of the condition of 'neutrality' [...] and demands that the social ranking of any pair of states be neutral to the non-utility features of the states, i.e. the concentration must be exclusively on the utility information about the states." It thus implies informational restrictions. However, as Sen argues, there are principles of social judgments that are under-discussed in traditional welfare economics - e.g. liberty, non-exploitation, nondiscrimination - that require use of non-utility information (Sen 1979: 547). ${ }^{2}$

On the other hand, Sen's critique of utilitarian approaches, more specifically to marginal utility, is strictly related to the notion of "equality" as referring to marginal 
utility. Utilitarianism is a moral principle relating to marginal utility, according to which each individual gets the same marginal utility when a fixed income is distributed among a set of individuals (assuming that marginal utility for each diminishes the more income an individual has). The equality of marginal utility embodies equal treatment of everyone's interests. The moral importance of an individual's needs is based exclusively upon the notion of marginal utility. The question, according to Sen, is: "whether the size of marginal utility irrespective of total utility enjoyed by the person, is an adequate index of moral importance" (Sen 1979: 200). Marginal utility measurements are automatically identified as indicators of social importance, ${ }^{3}$ but they say little about real human beings' interests. As Sen writes: "The recognition of the fundamental diversity of human beings does, in fact, have very deep consequences, affecting not merely the utilitarian conception of social good, but others as well" (Sen 1979: 202, emphasis mine; see also Sen 2000: 69-70). This is strictly intertwined with the criticism of the contemporary choice theory assumption according to which utility is the representation of a person's preference. However, if on the one hand this approach does not require us to compare different individual's mental conditions of pleasure or desire, on the other hand it foregoes "the possibility of direct interpersonal comparisons of utilities" (Sen 2000: 67-8). The difficulty cannot be overcome assuming the same choice of behavior and the same type of demand function. This is because, given interpersonal diversity related to both physical and psychical relational factors, interpersonal comparisons are "quite a distinct matter from explaining choice behavior" (Sen 2000: 69).

8 Summing up, Sen argues that an individual's well-being cannot be judged exclusively in terms of their utilities, and this is because people seem to have very different needs, varying with health conditions, climatic conditions, work conditions, and more general social and cultural background, as well as personal temperament and character.

\section{Needs, Interests, Identities}

The CA considers the active role things play in the needs of individuals. Individual's claims are thus assessed not by the resources or primary goods the individual possesses, but: "by the freedoms they actually enjoy to choose between different ways of living that they can have reason to value" (Sen 1990a: 114). ${ }^{4}$ This means that any individual has a partial ordering of needs and interests, and such partial ordering has to consider a broad uniformity of personal preferences, namely, the intensity of one's needs, as well as certain established conventions of relative importance (Sen 1979: 219), that is, some general social rules that contribute to general interests shared by people of the same cultural and social context. As Sen (2000: 296) puts it, three aspects of human capabilities have to be considered: 1) their direct relevance to the well-being and freedom of people; 2) their indirect role through influencing social change; and 3) their indirect role by influencing economic production.

Thus, a distinction should be made between "functionings," "achieved functionings," and "capabilities." Strictly related to this distinction, it is that between "achievements" and "valuable options" from which one can choose. A functioning is what a person manages to do or to be, and a person's capability amounts to the functionings that they could have achieved. The combination of a person's functionings reflects her actual achievements, whereas "the capability set represents the freedom to achieve: the 
alternative functioning combinations from which this person can choose" (Sen 2000: 75). ${ }^{5}$ Thus capabilities are derived from functionings, including all the information on the functioning combinations that a person can chose (see Sen 2009: 236). ${ }^{6}$ Sen formalizes this, arguing that a person's capability is represented by: "a set of $n$-tuples of funtionings from which the person can choose any one $n$-tuple" (Sen 1990a: 114). Hence capability is strictly related to ideas of opportunity, freedom, and advantage (see Basu \& López-Calva 2011).

11 A good has certain characteristics that the individual may consider of interest. But in order for an individual to convert the characteristics of a good into a functioning, there are some personal, social, and environmental conversion factors related to the circumstances that influence the choices that people make from the capability set. In particular, Sen distinguishes five sources of conversion factors that should be central to capability evaluations: 1) personal heterogeneities, namely, "disparate physical characteristics connected with disability; illness, age or gender, and these make their needs diverse"; 2) environmental diversities, related to climatic circumstances; 3) variations in social climate, "including public educational arrangements, and the prevalence or absence of crime and violence in the particular location"; 4) differences in relational perspectives, related to differences of conventions and customs between communities, and 5) distribution of incomes within the family (Sen 2000: 70-1, and 2009: 255-6).

Relevant personal characteristics govern the conversion of primary goods into an individual's ability to promote their ends. Two individuals with identical capability sets are likely to make different choices following various types and levels of achieved functionality as well as different ideas of what good life is. For sure, conversion factors matter because they have to do with a person's real opportunities, not only with what his or her own desiderata may be. If a person has physical disability, i.e. she is in wheelchair, and lives in a place where there are architectonic barriers, she will be obliged to make different choices respect to other people with no disabilities, despite the fact that they may share the same idea of what good life is. Moreover people are conditioned in their choices by their background and social norms, that is to say that no one is independent of the influences of the society in which they live. However, what I want to point out here, is that given two persons having the very similar abilities, or even disabilities, and having very similar capability sets as well, they may, and often do make different choices. Closely connected to personal characteristics is the socioenvironmental and the institutional context (broadly defined). An individual's identification with their social environment in itself draws attention to the tension, among on the one hand the sense of affiliation to a community and the conformation to a certain model of behavior, and on the other hand to the individual tendency to differentiate itself from inherited habits. The nature of community relationships is crucial to the conversion of personal resources into functionalities. As Sen writes:

To note the role of "thinking, choosing and doing" by individuals is just the beginning of recognizing what actually does happen (we do, of course, as individuals, think about issues and choose and perform actions), but we cannot end there without an appreciation of the deep and pervasive influence of society on our "thinking, choosing and doing." When someone thinks, chooses, and does something, it is for sure, that person - and not someone else - who is doing these things. But it would be hard to understand why and how he or she undertakes these activities without comprehension of his or her societal relations. (Sen 2009: 245) 

background. This is why it is not possible, according to Sen, to list particular capabilities, for different social, cultural, and geographical settings have different lists of capabilities which influence selection. As he puts it, the capability approach emphasizes an individual's "freedom to choose how to live - including the opportunity to pursue parts of her ancestral cultural preferences if so desired" (Sen 2009: 238; original emphasis). However, this freedom cannot be turned into an argument that supports those behavioral patterns irrespective of the individual's freedom to choose. ${ }^{7}$

Now the CA is strictly related to the way in which individuals elaborate their identities and how such identities condition desires, interests, and preferences, affecting practical judgments about desires outcomes, means, and ends-in-view in everyday life. As Sen notes, there are some social constraints that condition individual choice. This does not mean that such constraints are negative. On the contrary, they are closely interwoven with an individual's biography and personal identities, values, and preferences. As Sen points out, the self's identities are generated in a community and are related to rule-based conduct. The CA concerns the role of social influences on what people value about the life of the community in which they live and what influences shape their values. It is hard, he writes, "to envision cogently how persons in society can think, choose or act without being influenced in one way or another by the nature and working of the world around them" (Sen 2009: 244-5). More precisely, discussing the behavioral foundation of economics, Sen tackled the problem of "identity," stressing that: "community, nationality, class, race, sex, union membership, the fellowship of oligopolists, revolutionary solidarity, and so on, provide identities that can be, depending on the context, crucial to ourselves" (Sen 1985: 348; see also Sen 2009: 246). An individual's identities and concept of their own welfare can be influenced by the position of others in ways that may involve identifying with them. This means that the pursuit of self-interest may well be influenced by consideration for the interests of others in the group with whom the individual identifies. ${ }^{8}$ The recognition of interdependence of interests may suggest certain social rules of behavior which are of great instrumental importance in the improvement of the respective goals of the members of that group. ${ }^{9}$ As Sen writes: "between the claims of oneself and the claims of all lie the claims of a variety of groups - for example, families, friends, local communities, peer groups, and economic and social classes" (Sen 1977: 318). These are intermediate areas of concern, and even if we dismiss a merely utilitarian approach an egoistic approach is the is not the only alternative. Elsewhere he argues that:

One of the ways in which the sense of identity can operate is through making members of a community accept certain rules of conduct as part of obligatory behavior toward others in the community [...] acceptance of rules of conduct toward others with whom one has some sense of identity is part of a more general behavioral phenomenon of acting according to fixed rules, without following the dictates of goal-maximisation. (Sen 1985: 349)

an individual can act not only on the basis of given individual preferences but also on the basis of the importance attached to social interactions in the emergence of shared values and commitments. And social values "can play - and have played - an important part in the success of various forms of social organization" (Sen 2000: 261). ${ }^{10}$

In support of his thesis, Sen refers to Adam Smith's idea, expressed in The Theory of Moral Sentiments, according to which there are some general rules of conduct, that have been fixed in our minds by habitual reflection, that are of great use in correcting 
misrepresentation of self-love concerning what is appropriate in a particular situation (Smith 1790: 160). There is also a "natural selection" argument that supports such behavioral modes, leading to their survival and stability, as well as an evolutionary influence that works in a direction quite different from the survival of self-satisfaction (Sen 1985: 350, 1973: 252-3, and 2000: 272-4). Moral behavior tends sometimes to take the form of simply following established conventions. However, even when individuals are moved by the implications of moral arguments, they may perceive their choices: "in terms of acting according to some well-established practices in society" (Sen 2010: 56). Thus non-self-interested behavior is, according to Sen, the combination of deliberative and evolutionary selection within an integrated framework.

According to Sen, Smith's emphasis upon the importance of motives other than the pursuit of one's own gain shows that human beings are not invariably guided only by self-interest, and that: "there are good ethical and practical reasons for encouraging motives other than self-seeking" (Sen 2010: 53-4). Smith's approach of the 'impartial spectator' focuses on the relevance of the society in the "valuational exercise of individuals" (Sen 2009: 245). It refers to an "open impartiality," the "eyes of all mankind," that is, to view our sentiments and motives "with the eyes of other people, or as other people are likely to view them" (Smith 1790: III, 2). The "impartial" point of view permits us to consider other people's interests and give pertinence to other people's perspectives, hence to incorporate into the evaluative process an idea of "social justice." As Sen writes:

the basic ideas of justice are not alien to social beings, who worry about their own interests but are also able to think about family members, neighbors, fellow citizens and about other people in the world. The thought experiment involving the 'impartial spectator' that Adam Smith beautifully analyzed (beginning with the powerful question: What would an 'impartial spectator' make of it?) is a formalization of an informal - and pervasive - idea that occurs to most of us. Space does not have to be artificially created in the human mind for the idea of justice or fairness - through moral bombardment or ethical haranguing. That space already exists, and it is a question of making systematic, cogent and effective use of the general concerns that people do have. (Sen 2000: 262)

This does not mean that people think in the sense in which groups think, but that the interdependence of individual valuations is also related to the importance that they attach to being able to do certain things in collaboration with others.

So, it follows that the CA includes different social structures as one of its conceptual tools. The established social rules of behavior are shown to play a crucial role in conditioning more general human conduct.

\section{An Interdisciplinary Net as a Necessary Complement to Sen's Capability Approach}

20 In an article quoted by Sen in his The Idea of Justice (2009: 244), Stewart and Deneulin argued that Sen's CA has an "individualistic orientation of the approach." In particular, the authors maintain that CA "shares the individualism of the utilitarian approach," assuming that individuals are "atoms who come together for instrumental reasons only, and not as an intrinsic aspect of their way of life" (Stewart \& Deneulin 2002: 66). In other words, Sen would make "individual freedoms and capabilities the one relevant 
space for evaluation of quality of life, with structures of living together assessed only instrumentally" (Stewart \& Deneulin 2002: 68).

In a more recent paper, Deneulin and McGregor argued that "the capability approach as advanced by Sen, ultimately conceives of individual freedom in an individualistic light. This logically relates to the ethical individualism of the approach, where individual freedoms provide the yardstick for evaluating social arrangements" (Deneulin \& McGregor 2009: 4). In other words, CA does not consider sufficiently the dynamic social generation of meanings, "seen primarily in terms of positive or negative constraints" (Deneulin \& McGregor 2009: 19). For this reason in CA, "[f]ollowing the spirit of the enlightenment [the] individual is seen as analytically separable from society" (Deneulin \& McGregor 2009: 19). This analytical "separability" can be regarded both as an ethical as well as a methodological assumption, namely the assumption similar to that of the utilitarian approach in which individuals "are assumed to be atoms who come together for instrumental reasons only." However, even if the assumption of the individual as analytically separable from society can be considered as an ethical assumption, Sen discusses the position of Stewart and Deneulin as one position which wrongly identifies "capabilities approach as methodological individualism" (Sen 2009: 244). As also Robeyns argues: "It is difficult to see how the capability approach can be understood to be methodologically or ontologically individualistic, especially since Sen himself has analyzed some processes that are profoundly collective, such as his analysis of households as sites of cooperative conflict" (Robeyns 2005: 108). ${ }^{11}$

Even if Sen develops a paradigm in which individual identities and values are strictly intertwined with the recognition of the interdependence of community identity and the interests of others, it seems to me that a more specific in-depth analysis is needed to conceptualize how people's identities, values, desires and interests are constituted. In other words, the CA, for obvious reasons, lacks a theoretical tool to conceptualize social and psychological processes at the basis of the social construction of shared meanings, as well as of the constitution and conditioning of people's habits of thought and behavior. Whilst Sen highlights the elements that have to be considered in order to develop a more complete and articulated paradigm regarding human conduct, he does not offer (and he does not wish to offer) an epistemological tool to enter into an indepth analysis of its social and psychological constituents. Some important questions to which Sen's tool cannot reply can be summarized as follows: how are general rules of conduct fixed in our mind by habitual reflection? What are the bio-psycho-social processes at the basis of our corrective misrepresentation of self-love concerning what is appropriate to do in a particular situation? How has 'natural selection' led to the survival and stability of certain behavioral modes rather than others in a particular cultural context as opposed to another? How can evolutionary influence work in a direction other than to in that which guarantees the survival of self-satisfaction?

To reply to these questions, a more specific in-depth analysis is needed through a disciplinary net that blends conceptual elements of philosophy, psychology (social and cognitive), with the social and economic sciences. Such an analysis would enable us to conceptualize how individual identities expressed in their values, desires, interests, economic preferences relate to their "ways to behave" are constituted. Thus, it would offer a useful theoretical tool to understand evaluative purposes, what individuals 
manage to do or to be, the functionality they choose in regard to social opportunities, their freedom, and the consequences of their choices.

This disciplinary blend would be particularly valid for economic science, I argue. In fact, assuming that economic preferences and choices are part of the most general category of "human conduct," which represents in everyday life the manifestations of self-identity generated in a community and related to rules-based conduct, we see that economics, seen as a social science more than a mathematical one, is part of a more general frame which aims to understand human conduct and behavior. ${ }^{12}$ However, since economic language makes it hard to discuss patterns of social behavior, given the ambiguity of the instrumental value of certain social rules in influencing processes of choice, a wider approach, namely Mead's pragmatist approach to human behavior, would offer a good starting point to develop a new theoretical frame, a sort of paradigm concerning human conduct in which the disciplines which engage with different components of self are seen as functionally intertwined in a complex model of human conduct. Thus it is possible to discover some interesting connections between Sen's paradigm and Mead's social theory of the self which would implement the CA from a trans-disciplinary perspective. This trans-disciplinary paradigm aims to address the ways through which options are constituted, as well as ideas of being what people want to be and do. In other words, a connection between Sen's and Mead's approaches will offer the conceptual tools which would help clarify how individuals evaluate the "valuable" life and, by extension, how they develop their attitudes and dispositions to think and behave, namely the habits at the basis of their everyday practical judgments. 13

\section{Mead's Bio-Social Theory of the Self and Human Conduct as the Framework for the Interdisciplinary Net}

In a 1911 review of Benjamin M. Anderson's Social Value: A Study in Economic Theory. (Critical and Constructive), Mead highlights that many social forces besides economic processes shape economic values. However, while economists admitted at the time the real influence of social conditions and organization upon economic goods, their theories and methods "hark back to the individualistic period with its contract theory of society and its Humean psychology" (Mead 1911: 433). ${ }^{14}$ Thus Mead shared Anderson's thesis according to which: "values can be conceived to exist only as social phenomena. They arise not through the addition of the pleasures and pains of men, but through organized social activity which is supra-individual" (Mead 1911: 433). Connecting Cooley's sociology with Dewey's functional psychology, Anderson argues that social organization gives the funded meanings which reinforce and enforce values. These values lie in individual consciousness as forces, motivations, namely emotionalvolitional attitudes, which cannot be measured (economically) for the attitudes are not reducible to feelings of pleasure and pain, nor to bare desires. Rather, they enforce the entire conduct of the individual involving a feeling of reality.

However, Mead noted, Anderson's thesis, which uses social psychology to interpret economic theory, does not fill the gap between social sciences and social psychology. More specifically, Anderson does not succeed in tracing a functional relationship 
between the sociological notion of value as a phenomenon of social organization and the psychological notion of value as an emotional-volitional attitude. He rather still uses a parallel approach which does not overcome the dualistic methodological perspective on the issue. The main question that Mead posed was: What are the conditions under which value takes the form of funded meanings in the social organization, and under what conditions does they appear as emotional-volitional attitudes? As he argued, if values arise out of mutual interaction and mutually determination of individual ends, purposes, desires that take tangible, determinate shape as economic values, this means that the process of evaluation has to be seen as a functional interaction between the world as a social object and the self-as-subject. But there is here a circular process. What was funded, namely social meaning, becomes emotional-volitional attitude, and what is emotional-volitional attitude becomes meaning. It follows that meaning is an attitude to act, namely a way to give meaning, to select and evaluate the world as social object and to give some of these evaluations a measure (an economic measure). Mead concluded that: "It is in the process of stating the attitude in terms of funded meaning that we must evaluate it - measure it against other attitudes and determine what is its economic sum as compared with that of other emotional-volitional attitudes that arise demanding their expression" (Mead 1911: 435-6). Some 20 years later, in a critical paper published in 1930, one year after Cooley's death, Mead, in a similar way, denounced the limits of Cooley's sociology. In particular, he argued that Cooley had accepted the psychophysical parallelism of "ordinary psychology," so ignoring primitive impulses of social behavior antecedent to the distinction of psychical and outer world dimensions. Cooley's conception of the relation of the social mind to the organic structure and process of society sees the structure and process as external, even if they are the structure and process of a living reality, whose interrelationships make possible the social mind in individuals. As Mead put it, Cooley's interpretation was that consciousness is an internal experience of the life of the external organism, so setting up in ordinary psychology a "parallelism between sensations, percepts, emotions, volitions, and so forth, and physiological processes" (Mead 1930: 701-2). This implies that it is possible to give a scientific account of the physiological process without introducing parallel states of consciousness. The question, asked in the review of Anderson's book, had here become: "whether society is itself psychical or whether the form of the psychical is a sort of communication which arises within primitive human behavior" (Mead 1930: 705). And this question was related to another core question which at the time preoccupied Mead's investigations: How it is possible to overcome the individual/social dichotomy and explain the passage from emotional-volitional attitudes to meaning in a shared social act?

27 Mead had replied to this question by developing a social theory of the Self which, rather than presupposing the individual to the social, attempts to intertwine biological mechanism with reflective processes of organic interaction between individuals on the one hand and social and physical environments on the other.

According to Mead (1925), the human organism assumes the attitude of another which it addresses by vocal gesture, and in this attitude, it addresses itself, thus giving rise to its own self and to the other. In the process of communication "there appears a social world of selves standing on the same level of immediate reality as that of the physical world that surrounds us. It is out of this social world that the inner experiences arise which we term psychical, and they serve largely in interpretation of this social world as psychical sensations and percepts serve to interpret the physical objects of our environment" 
(Mead 1930: 704). The symbolic mediation is in an interdependent relation with the individuals' signification of their relations with others and with the surrounding reality. The "social meanings" are product of individuals' ability to select and evaluate stimuli on the basis of attitudes shared by the group to which they belong that uses a semiotic frame of reference for the interpretation, processing, and valuation of accepted behaviors. The individual process of semiotic interpretation of reality is thus a process that simultaneously determines their beliefs and the meanings they attribute to the surrounding reality, and it is the process that conditions the constitution of their identities.

\section{Mead's Social Psychology and Philosophy as the Counterpart of Sen's Capability Approach}

Individuals acquire their identities through communication processes in which the organized community or social group gives the individuals their unity as self. The sum of the vocal and gestural replies of others to an individual's stimuli constitute the attitude of the whole community towards the individual's behavior. Mead called such a social attitude the 'generalized other,' depicting it as the crystallizing of all particular attitudes into a single attitude or standpoint (Mead 1934: 90). Individuals take the general attitude towards the various phases or aspects of the common social activity or set of social undertakings in which, as members of an organized society or social group, they are engaged. As Mead argues:

Only in so far as [the individual] takes the attitudes of the organized social group to which he belongs toward the organized, cooperative social activity or set of such activities in which that group as such is engaged, does he develop a complete self or possess the sort of complete self he has developed. And on the other hand, the complex cooperative processes and activities and institutional functioning of organized human society are also possible only in so far as every individual involved in them or belonging to that society can take the general attitudes of all other such individuals with reference to these processes and activities and institutional functionings, and to the organized social whole of experiential relations and interactions thereby constituted - and can direct his own behavior accordingly. (Mead 1934: 155)

Behind the common social activity there is a set of social primitive instincts according to the nature of which the distinction between me and the other is given. The instincts are social in the sense that the individual's gestural and vocal responses arise in answer to indications of various movements by other individuals of the group. We briefly recall here Mead's thesis of the emergence of human consciousness from the earliest stages of the proceedings in which are rooted emotional attitudes. According to his thesis, the inhibition due to the conflict of impulses stimulates the preparation of the act in its earliest stages. The emotional tension takes over the function of showing to others the answer that the individual is going to implement over the stimulus received, so that the other individuals can respond in turn to the stimulus of the first individual. Emotion is therefore already communication and immerses the body of individuals in this innate communicative dimension. ${ }^{15}$

Behind this idea are Mead's and Dewey's Theory of Emotion (Mead 1895; and Dewey 1894, and 1895), according to which the expression of certain emotional attitudes constitute evidence of the passing over of emotional attitude as a "mode of behavior" into the 
"communicative gesture" (see Dreon 2016; Baggio 2015; and Garrison 2003). The progress of more controlled gestures consists in transforming potential reflex actions expressions of strong emotional power - into actions characterized by interest (rather than passion). The distinction between interest and passion marks the dividing line between individual instincts connected to immediate consummation of needs and the social instincts - e.g. the urge to fight is an outgrowth of the process of food consumption, that is, a socializing process of something primarily individual. The early stages of these activities give rise in the individual, along with antisocial sociophysiological impulses (Mead 1934: 303-4), to what is currently called pro-social emotions, namely, psycho-physiological reactions to movements of other group members that induce agents to engage in cooperative behavior (cf. Bowles \& Gintis 2011). The bio-social mechanism is in fact at the basis of the feeling of sympathy, which consists, according to Mead's definition, in "a distinctively human, that is, selfconscious, social attitude toward another individual [...] is to identify yourself sympathetically with him, by taking his attitude toward, and his role in, the given social situation, and by thus responding to that situation implicitly as he does or is about to do explicitly" (Mead 1934: 300). Mead depicts sympathetic identification as a natural process presenting both cognitive and affective aspects, since it refers to both the capacity to represent the other's intentions and beliefs (attitudes) and to share their feelings. ${ }^{16}$

Mead's notion of sympathy has its philosophical basis in David Hume's Treatise of Human Nature and in Adam Smith's The Theory of Moral Sentiments, in which sympathy is referred to as a quality of human nature at the basis of communication and social rules. According to Hume (1740: Bk II, Part II, Sec. V), sympathy is a disposition to share sentiments, to participate in the emotional life of others, and to form general rules. Smith, who further elaborates Hume's use of sympathy, ${ }^{17}$ considers sympathy to be an individual's "fellow-feeling with any passion whatever" which may arise from "the view of a certain emotion in another person," but not "from the view of the passion, as from that of the situation which excites it" through the imagination (Smith 1790: I, I, 1, $\S 10)$. This is due to the fact that people have learned from experience ways to approve or disapprove of the opinions of others (I, I, 3, §§ 3-4), as well as their own (III, 1, §§ 4-5). According to Smith, sympathy is a complex imaginative process that presents an emotive content and helps the individual to evaluate a complex situation in order to approve or disapprove. Thus sympathy is involved in moral evaluations which can also be self-evaluations.

33 As Mead argues: "It is in the form of the generalized other that [...] the community exercises control over the conduct of its individual members; for it is in this form that the social process or community enters as a determining factor into the individual's thinking" (Mead 1934: 155). And in societies that have an organized legal system that prevents hostile impulses giving rise to violence, anti-social impulses are directed to the functioning of the economic system and to attitudes of rivalry and competition. In other words, human impulses of hostility find their exhaust device in the dynamics of social conflict between different economic classes. The economic process of exchange necessarily, consequently, depends upon an identification of the self with the other, and this can take place between living forms in which there is the ability to put oneself in another's place through communication. The mechanism of communication carries with it the possibility of conversation with others, but also with those who are not members of the group, for the social pattern is larger than the group that it makes 
possible, including enemies, guests, and the morals of behavior toward them. Thus the logical universe of discourse is implicated and with it the possibility of shared meanings and values of exchange. From such a point of view, economic exchange has to be seen as a symbolic mediation in which the decision is strictly linked to the process of identification with the others (see Mead 1934: 300-2).

Like Mead, Sen argues that the demands of ethical objectivity have close connections with our language, which "reflects the variety of concerns on which our ethical assessments draw" (Sen 2009: 119). Whilst Sen refers here to Gramsci's assertion, ${ }^{18}$ as well as to Putnam (2002) and Walsh (2003), what he intended to shed light upon is, close to Mead, the central role communication assumes in the process of reasoning and public discussion. As he writes:

The need of objectivity for communication and for language of public reasoning is followed by the more specific requirements of objectivity in ethical evaluation, incorporating demands of impartiality. Objectivity in each sense has a role in the exercise in public reasoning, and the roles are interrelated but not exactly the same. (Sen 2009: 122)

\section{Sympathy and Commitment}

It seems now possible to look at the CA from the perspective of Mead's theory of the genesis of the self as social and communicative in nature. In particular, it is possible to consider Mead's idea of 'social conduct' and social construction of meanings together with Sen's argument of a "natural selection" of certain pro-social behavioral modes based on an evolutionary influence. This integrated approach allows us to regard the mesh of physical, mental, and social dimensions of interaction with the social and physical worlds as the basis of the constitution of persons' identities as well as their shared desires, self- and other-regarding interests, preferences and choices.

The experiences that individuals have and their proximity to others occur in relation to what Mead calls the "generalized other," namely the: "organized community or social group which gives to the individual his unity of self" (Mead 1934: 154). The attitude of the 'generalized other' is the attitude of the whole community, namely the common ethos which gives unity and consistency to individual identity. ${ }^{19}$ The community's identity is thus embedded in the self as a co-determining factor of their evaluation of preferences and choices. People's social attitudes, which in part contribute and in part are subject to community values (often non-commensurable values), ${ }^{20}$ offer the basis for taking into account the attitudes of others through which private subjective preferences become potentially shareable. Thus, social interaction is also the 'shared place' in which all aspects of freedom contribute to the constructive role individuals play in the formation and modification of their community's values and ethics, for the importance of capabilities that groups enjoy are based on the value that members of the group or other people "place on the proficiency of that group" (Sen 2009: 246). In other words, the organization of social groups is related to the organization of the members' roles arising within the social process in which that group is engaged, or which it pursues. The nature of what Sen (2009: 255-6) calls "community relationship" or "social capital" (referring to Robert Putnam 2000), as well as the relational perspectives, in particular of the personal resources needed for taking part in the life of the community, is in accord with Mead's idea that 
'social' aspect of human society - which is simply the social aspect of the selves of all individual members taken collectively - with its concomitant feelings on the parts of all these individuals of cooperation and social interdependence, is the basis for the development and existence of ethical ideals in that society. (Mead 1934: 321)

In fact, according to Mead, concrete personal interests are reconstructed in their relations to other selves' interests, whose relations are essential to one self's identity (see Mead 1964: 149). Thus, the social norms are based on feelings of cooperation and social interdependence, and paraphrasing Robert Putnam we may say that ethical ideals have to be "embedded in a dense network of reciprocal social relations" from which arise reciprocity and trustworthiness (Putnam 2000: 16). In other words, what is essential to ethical ideals of a society is "an organization of common attitudes which shall be found in all individuals" (Mead 1934: 323) and which characterizes the "social capital" as well as "its conceptual cousin": the "community" (Putnam 2000: 19). ${ }^{21}$

Sen would then agree with Mead's explanation of the Self as constituted socially and following particular rules of conduct. And he would agree with Mead's idea that a "multiple personality is in a certain sense normal" (Mead 1934: 142). According to Mead, in fact, we all have multiple identities, dividing "ourselves up in all sorts of different selves with reference to our acquaintances" (Mead 1934: 143). Expressed differently, the various elementary identities which are organized into a complete Self are the various aspects of that complete Self related to the various aspects of the social process, and the structure of the complete Self is "a reflection of the complete social process" (Mead 1934: 144). Consonant with Mead's claim, and responding to those authors who criticized his CA to conceive human freedom in an individualistic light (Deneulin \& McGregor 2009; Evans 2002; and Gore 1997), Sen argues that:

Individual human beings with their various plural identities, multiple affiliations and diverse associations are quintessentially social creatures with different types of societal interactions. Proposals to see a person merely as a member of one social group tend to be based on an inadequate understanding of the breadth and complexity of any society in the world. (Sen 2009: 247)

This does not mean that one's multiple social identities are in certain crucial ways matters of personal choice. On the contrary, multiple identities are part of the complexity of society in which human beings live. Such a claim implies the connection of CA to Mead's theory of the social self more urgent, for the latter offers some elements that are useful to explain the development of the plural identities of human beings, their evaluation of the lives they want to live and the interests they have reason to pursue, and what influences operate on their evaluative processes.

Furthermore, Sen's highlighting Smith's concept of an 'impartial spectator' as a notion that has much to contribute to a fuller understanding of what it means to go beyond individual's and local groups' particular interests and concerns, is at the core of the possible interdependence between Mead's and Sen's approaches. In particular, as we have seen, Sen argues that one of the main motivations of Smith's use of the "impartial spectator" was to broaden human understanding and to widen the reach of ethical inquiry. The "impartial spectator" is related to an "open impartiality" invoking disinterested judgments of spectators not necessarily belonging to the local group. The impartial view "may come from far or from within a community, or a nation, or a culture" (Sen 2009: 123).

41 On this point, it is worth noting the similarities between Mead's "generalized other" and Smith's "impartial spectator." These similar notions highlight the crucial role that 
imagination assumes in both authors' moral theories, and specifically in their ideas concerning individual learning of social rules by taking "the role of the other" as well as the perspective of the "interior man" (as Smith called the impartial spectator in his Theory of Moral Sentiments). For both authors, the ability to put oneself in another's shoes is related to the acquiring of a shared perspective on human meanings and conducts. Mead's distinction between "me" and "I," the first indicating the historical Self as well as the Social perspective about rules, as opposed to the I as the active and impulsive self, is close to the distinction Smith makes in the sixth paragraph of the third part of the The Theory of Moral Sentiments between two versions of "I," "the examiner and judge," and "the person whose conduct is examined into and judged of." As Smith argues (III, 1, § 6), the first "I" "is the spectator, whose sentiments with regard to my own conduct I endeavour to enter into, by placing myself in his situation, and by considering how it would appear to me, when seen from that particular point of view. The second is the agent, the person whom I properly call myself, and of whose conduct, under the character of a spectator, I was endeavouring to form some opinion."

Now from Mead's perspective, one could say that the self's behavioral attitudes toward others show the interdependence between communal goals and self's goals at the core of social acts, without implying either the identification between self-interest and the interests of others or, by contrast, the idea that communal goals are the products of a pure sentiment of altruism. Habitual reflection is in fact based upon the embedded ability of learning social habits, namely social rules of actions. Habits would result from the action of natural selection consisting in a process of empirical generalization through which habits became normative. As Mead writes (Mead 1934: 379), we "are what we are through our relationship to others. Inevitably, then, our end must be a social end, both from the standpoint of its content (that which would answer to primitive impulses) and also from the point of view of form." He continues:

One is constituted out of his own interests; and when those interests are frustrated, what is called for then is in some sense a sacrifice of this narrow self. This should lead to the development of a larger self which can be identified with the interests of others. I think all of us feel that one must be ready to recognize the interests of others even when they run counter to our own, but that the person who does that does not really sacrifice himself, but becomes a larger self. (Mead 1934: 386) ${ }^{22}$

This offers a theoretical tool to explain Sen's distinction between sympathy and commitment. The former corresponds "to the case in which the concern of others directly affects one's own welfare" (Sen 1977: 326). The conception of self-interest may in fact include the individual's concern for others, and "sympathy may thus be incorporated within the notion of the person's well-being, broadly defined" (Sen 2000: 270). Then the pursuit of one's own utility may be assisted by pleasure taken in others' pleasures and the pain wrought by others' pain. In contrast, commitment is concerned with breaking the link between a person's welfare and their choice of action through predictions of welfare states, driving a wedge between personal choice and personal welfare. Thus, it is related to the intrinsic importance of the role of agency and the influence that this role has on the individual's evaluation of what is valuable. Commitment is closely connected to anticipated welfare levels, that is, to the possibility of postponing some sorts of acts of consummation connected to the choice of personal welfare. To refer to anticipated levels excludes acts against "self-interest resulting purely from a failure to foresee consequences" (Sen 1977: 327). As Sen puts it: "man is a social animal and his choices are not rigidly bound to his own preferences only [...]. An 
act of choice for this social animal is, in a fundamental sense, always a social act" (Sen 1973: 252-3). It is possible that a person may be induced by social codes of behavior to act as if she has different preferences from what she really have and then that her choices may be guided by motives, the pursuit of personal well-being being only one of them. In other words, a person may be willing to make sacrifices invoking "values other than personal well-being or self-interest (including the self-interest involved in promoting the interests of those with whom we sympathize)" (Sen 2000: 270. See also Sen 1985: 188).

The core concept here is that of preference, the normal use of which identifies it with the concept of "being better off," and preferred with chosen (Sen 1977: 329). Commitment is then a part of behavior. It does not presuppose rationality but it does not exclude it: "insofar as consequences on others have to be more clearly understood and assessed in terms of one's values and instincts, the scope for reasoning may well expand" (Sen 1977: 344). ${ }^{23}$

Connecting these reflections to $\mathrm{CA}$, we can then argue that, according to Sen, such an approach is concerned with both interpersonal interdependence, that is, being influenced by other people's habits (Sen 1977: 330), and the social opportunities people have to improve the quality of their lives. To refer to the adjective "social" is to remind: "not to view individuals and their opportunities in isolated terms. The options that a person has depend greatly on relations with others and on what the state and other institutions do" (Drèze \& Sen 2002: 6). ${ }^{24}$ Given such a point of view, it is possible to refer to Mead's idea that: "To do justice to the recognition of the uniqueness of an individual in social terms, there must be not only the differentiation which we do have in a highly organized society but a differentiation in which the attitudes involved can be taken by other members of the group" (Mead 1934: 325).

\section{Conclusion}

Sen's approach to capability is based on the role of agency and pays attention to social structures and groups. Thus, it is connected to issues of social change. He argues that people have to have more freedom to live the kind of life that, upon reflection, they have reason to value. Our evaluations should focus upon what we are able to do and be, on the quality of people's lives, and on removing obstacles so that they have the chance to lead the kind of life they wish to live.

47 According to Robeyns, to fully understand the importance of groups in the constitution of opportunities, the CA "should engage more intensively in a dialogue with disciplines such as sociology, anthropology, history, and gender and cultural studies" (Robeyns 2005: 109). But also, in my opinion, with social and cognitive psychology and communicative sciences as functional dimensions of the constitution of individual preferences and practical judgments. Social structures and institutions have an important effect on capability sets. It is crucial to know both the psychical and social determinants of the relevant capabilities, as only these determinants can be changed.

This would also be of great importance to the study of individual economic behavior. It offers some new elements for constructing a more complete theoretical framework of human nature and conduct (see Baggio 2017). This would also help us to develop some experimental hypothesis to test the consistency of day-to-day behavior. 
Mead's socio-psychological approach to human behavior offers a new theoretical framework, a kind of paradigm to develop a new idea of human conduct in which the different components of self are seen to be functionally intertwined in a social structure. To re-think Mead's theory of social self in the light of a wider perspective on human conduct and decision-making processes would strengthen, at once, the principled commitment to freedom of choice, revealing in a 'Mead-Sen' perspective, as it were, the instrumental role of behavioral patterns and socio-cultural environment (social group, community, nationality, race, sex, and now increasingly, social media) in the orientation of individual behaviors. Since, in fact, choices are products of acts of evaluation, namely "evaluative judgments" (Sen 2000: 80), and such acts have moral significance, my proposal would help us to enlarge the theoretical framework of capability, opening the way to a wider theory of synthetic reasoning and judgment processes from a pragmatist point of view. Moreover, if it is true that, as Sen puts it, in "valuing a person's ability to take part in the life of the society, there is an implicit valuation of the life of the society itself" (Sen 2009: 246), pragmatism would offer a theoretical contribution to the CA in the selection of the various informational foci that influence the assessment of societies and social institutions concerned with a plurality of different features of individual's lives and concerns, addressing "a bit more reality than a picture of a world in which there is only one good thing" (Sen 2009: 240).

\section{BIBLIOGRAPHY}

BAGGIO G., (2015), La mente bio-sociale. Filosofia e psicologia in G. H. Mead, Pisa, ETS.

BAGGIO G., (2016a), “The Influence of Dewey's and Mead's Functional Psychology Upon Veblen's Evolutionary Economics," European Journal of Pragmatism and American Philosophy 8 (1).

BAGGIO G., (2016b), "Sympathy and Empathy. G. H. Mead and the Pragmatist Basis of

(Neuro)Economics," in R. Madzia \& M. Jung (eds.), Pragmatism and Embodied Cognitive Science: From Bodily Interaction to Symbolic Articulation, Berlin/Boston, de Gruyter GmbH, 185-210.

BAGGIO G., (2016c), “Pragmatist Semiotics and Economic Behavior," Paradigmi, XXXIV (3), 119-33.

BAGGIO G., (2017), "Mead's Bio-social Theory of the Self and the Economics of Happiness. For a Pragmatist Philosophy of Economics," in K. Stikkers \& K. Skowronski (eds.), Philosophy in the Time of Crisis. Essays on Pragmatism and Economy, New York, Routledge, 2017 [forthcoming]

BALDWIN J. D., (1992), "Social Behaviorism on Emotions: Mead and Modern Behaviorism Compared," in P. Hamilton (ed.), George Herbert Mead. Critical Assessments, vol. III, New York, Routledge, 237-63.

BASU K. \& L. LOPEZ-CALVA, (2011), “Functinings and Capabilities," in K. Arrow, A. Sen, \& L. Suzumura (eds.), Handbook of Social Choice and Welfare, volume 2, North Holland, Elsevier Science, 153-87.

BOWLES S. \& H. GINTIS, (2011), A Cooperative Species. Human Reciprocity and Its Evolution, Princeton and Oxford, Princeton University Press. 
BRÉBAN L., (2015), “An Investigation into the Smithian System of Sympathy: From Cognition to Emotion," The Adam Smith Review, 9.

DE MUNCK J. \& B. ZIMMERMANN, (2015), “Evaluation as Practical Judgment,” Human Studies 38, 113-35.

Deneulin S. \& J. A. MCGREgor, (2009), “The Capability Approach and the Politics of a Social Conception of Wellbeing," WeD Working Paper 09/43 [welldev.org.uk/wed-new/workingpapers/ workingpapers/WeDWP_09_43.pdf].

DEWEY J., (1894), The Theory of Emotion, in John Dewey: The Early Works, Vol. 4, edited by J. A. Boydston, Carbondale, Southern Illinois University Press, 1971.

DEWEY J., (1895), The Theory of Emotion, in John Dewey: The Early Works, Vol. 4, edited by J. A. Boydston, Carbondale, Southern Illinois University Press, 1971.

DEWEY J., (1916), The Logic of Judgment of Practice, in John Dewey: The Midde Works, Vol. 8, edited by J. A. Boydston, Carbondale, Southern Illinois University Press, 1979.

DEWEY J. \& J. H. TUFTS, (1932), Ethics (revised edition), New York, Henry Holt and Company, 1952.

DREON R., (2016), “Emozioni pragmatiste,” in M. Striano, S. Oliverio \& M. Santarelli (a cura di), Nuovi usi di vecchi concetti. Il metodo pragmatista oggi, Milano, Mimesis, 151-64.

DRÈZE \& SEN, (2002), India, Development and Participation, Oxford, Oxford University Press.

EVANS P., (2002), “Collective Capabilities, Culture, and Amartya Sen's Development as Freedom," Studies in Comparative International Development, 37 (2), 54-60.

FREGA R., (2006), Pensée, expérience, pratique. Essai sur la théorie du jugement de John Dewey, Paris, L'Harmattan.

FREGA R., (2008), “Una logica per il giudizio di pratica," in J. Dewey, Logica sperimentale. Teoria naturalistica della conoscenza e del pensiero, Macerata, Quodlibet.

FREGA R., (2014), “Between Pragmatism and Critical Theory: Social Philosophy Today," Human Studies, 37 (1), 57-82.

GARRISON J., (2003), “Dewey's Theory of Emotions: The Unity of Thought and Emotion in Naturalistic Functional “Co-ordination' of Behavior," Transactions of the Charles S. Peirce Society, 39 (3).

GORE C., (1997), "Irreducibly Social Goods and the Informational Basis of Amartya Sen's Capability Approach," Journal of International Development, 9 (2), 235-50.

GRAMSCI A., (1975), Letters from Prison, London, Jonathan Cape.

HUME D., (1740), A Treatise of Human Nature, edited by L. A. Selby-Bigge, M. A. Oxford, Clarendon Press, 1896.

KAHNEMAN D. E., (2011), Thinking, Fast and Slow, New York, Farrar, Straus and Giroux.

KAHNEMAN D. E., WAKKER P., \& R. SARIN, (1997), "Back to Bentham? Exploration of Experienced Utility," Quarterly Journal of Economics, 112, 375-405.

KLAMER A., (2003), “A Pragmatic View on Values in Economics," Journal of Economic Methodology, 10 (2), 191-212.

LIOTTI G., (2005), La dimensione interpersonale della coscienza, Roma, Carocci.

MAX-NEEF M. \& P. EKINS, (1992), Real-Life Economics: Understanding Wealth Creation, London, Routledge. 
MEAD G. H., (1895), “A Theory of Emotions from the Physiological Standpoint (Abstract of a paper read to the third annual meeting of the American Psychological Association, 1894)," Psychological Review, 2, 162-4.

MEAD G. H., (1911), "Review of Social Value: A Study in Economic Theory (Critical and Constructive), by B. M. Anderson Jr.," Psychological Bulletin 8, 432-6.

MEAD G. H., (1925), “The Genesis of the Self and Social Control," International Journal of Ethics, 35, 251-77, republished in Selected Writings, edited by Andrew Reck, Chicago, University of Chicago Press 1968.

MEAD G. H., (1930), “Cooley's Contribution to American Social Thought," American Journal of Sociology, XXXV, 693-706.

MEAD G. H., (1934), Mind, Self, and Society, edited by Charles W. Morris, Chicago, University of Chicago Press.

MEAD G. H. (1964), Selected Writings, edited by Andrew J. Reck, Chicago, University of Chicago Press.

MEAD G. H., (2001), Essays on Social Psychology, edited by Mary Jo Deegan, New Brunswick, NJ, Transaction Publishers.

NuSSBAUM M., (2000), Women and Human Development: The Capability Approach, Cambridge, Cambridge University Press.

PANKSEPP J., (1998), Affective Neuroscience: The Foundations of Human and Animal Emotions, Oxford, Oxford University Press.

PUTNAM R., (2000), Bowling Alone: Collapse and Revival of American Community, New York, Simon \& Schuster.

PUTNAM H., (2002), The Collapse of the Fact/Value Dichotomy, and Other Essays, Including The Rosenthal Lectures, Cambridge, Harvard University Press.

RAWLS J., (1982), “Social Unity and Primary Goods," in A. Sen \& B. Williams (eds.), Utilitarianism and Beyond, Cambridge, Cambridge University Press.

ROBEYNS I., (2005), “The Capability Approach: A Theoretical Survey,” Journal of Human Development, $6(1), 93-114$.

SEN A., (1973), "Behaviour and the Concept of Preference," Economica, 241-59.

SEN A., (1977), "Rational Fools. A Critique of the Behavioral Foundations of Economic Theory," Philosophy \& Public Affairs, 6 (4), 317-44.

SEN A., (1979), "Personal Utilities and Public Judgements: Or What's Wrong With Welfare Economics?," The Economic Journal 89, 537-58.

SEN A., (1985), “Goals, Commitment, and Identity," Journal of Law, Economics and Organization, $341-55$.

SEN A., (1987), On Ethics and Economics, Oxford, Basil Blackwell

SEN A., (1990a), “Justice: Means Versus Freedoms," Philosophy and Public Affairs 19, 111-21.

SEN A., (1990b), “Gender and Cooperative Conflicts," in I. Thinker (ed.), Persistent Inequalities, Oxford, Oxford University Press.

SEN A., (1992), Inequality Reexamined, Oxford, Oxford University Press. 
SEN A., (2000), Development as Freedom, New York, Alfred A. Knopf.

SEN A., (2009), The Idea of Justice, Cambridge, MA, The Belknap Press of Harvard University Press.

SEN A., (2010), “Adam Smith and Contemporary World," Erasmus Journal for Philosophy and

Economics, 3 (1), 50-67.

SHARMA S. \& M. SHARMA, (2010), “Self, Social Identity, and Psychological Well-Being," Psychological Studies, 55 (2), 118-36.

SMITH A., (1790), The Theory of Moral Sentiments, D. D. Raphael \& A. L. Macfie (eds.), Oxford, Oxford University Press, 1976.

STEWART F. \& S. DENEULIN, (2002), “Amartya Sen's Contribution to Development Thinking,” Studies in Comparative International Development, 37 (2), 61-70.

TILMAN R. \& T. KNAPP., (1999), “John Dewey’s Unknown Critique of Marginal Utility Doctrine: Instrumentalism, Motivation, and Values," Journal of the History of the Behavioral Sciences, 35 (4), 391-408.

VEBLEn T., (1899a), “The Preconceptions of Economic Science. Part I,” The Quarterly Journal of Economics, 13 (2), 121-50.

VEBLEN T., (1899b), “The Preconceptions of Economic Science. Part II,” The Quarterly Journal of Economics, 13 (4), 396-426.

VEBLEn T., (1900), “The Preconceptions of Economic Science. Part III,” The Quarterly Journal of Economics, 14 (2), 240-69.

VEBLEN T., (1909), “The Limitations of Marginal Utility,” in C. Camic \& G. M. Hodgson (eds.), Essential Writings of Thorstein Veblen, London and New York, Routledge, 2011

WALSH V., (2003), “Sen after Putnam,” Review of Political Economy, 15, 315-94.

Zimmermann B., (2006), "Pragmatism and the Capability Approach. Challenges in Social Theory and Empirical Research," European Journal of Social Theory, 9 (4), 467-84.

\section{NOTES}

1. In speaking of "judgment of practice" or of "practical judgment," I refer here to Dewey's essay on The Logic of Judgment of Practice (1916) in which Dewey defines the practical judgment as "a kind of judgment having a specific type of subject-matter," namely a judgment: "of a situation demanding action" (Dewey 1916: 14). The object of the practical judgment "implies an incomplete situation," and it is: "about the situation in which one is included, and in which a multitude of other factors external to self are included" (Dewey 1916: 16). On Dewey's logic of practical judgment, see Frega (2006: 143-68, and 2008: ix-xxxiii). On the comparison between Sen and Dewey on the process of evaluation as a practical judgment, see De Munck \& Zimmermann 2015. 2. According to Sen (1979: 538), there are three properties of welfarist approaches: Welfarism "is a function of personal utility levels, so that any two social states must be ranked entirely on the basis of personal utilities in the respective states (irrespective of the non-utility features of the states)"; Ordinalism, namely the ordinal properties of individual utility functions; Noncomparable utilites, namely the indipendence of the social walfare ranking of the way the utilities of different individuals compare with each other; Pareto Preference Rule: if everyone has more utility in $x$ as in $y$, and if someone has more utility in $x$ than in $y$, then $x$ is socially better than $y$. The main problems of such approaches are the informational restrictions implicit in these conditions and 
that they are strictly related not exclusive to the evaluation of outcomes but more to a corresponding assessment of right action.

3. The utility numbering interprets ignorance as equal probability between different choices (Sen 1979: 200).

4. Primary goods are in a "relationship between persons and goods" (Sen 1979), namely, a relationship in which good things do something to human beings. Sen refers to Rawls' principle of justice, speaking of primary goods as: "things that every rational man is presumed to want." Sen criticizes Rawls' principle of justice (1982) according to which there are five groups of primary goods the bundle of which have to maximize the minimum: basic liberties; freedom of movement and choice of occupation; powers and prerogatives of offices and positions of public responsibility; income and wealth, and the social bases of self-respect. The first two are prior to the pursuit of the others. Sen (1979) criticizes Rawls' proposal arguing that he tends to be "primary good fetishist." Summing up, Sen criticizes Rawls' defense of 'impartiality' (justice as fairness) and "mutual advantage" based on the "veil of ignorance" argument, claiming that individuals behind the 'veil' would choose the maximum principle over an index of primary goods as the accepted social contract (Basu \& López-Calva 2011: 162; Sen 2009: 52-74). It is important, Sen argues, "to distinguish capability - representing freedom actually enjoyed - from both (1) primary goods (and other resources), and (2) actually chosen lives (and other realized results)" (Sen 1990a: 116; see also Sen 1992). Related to this is the distinction between freedom and the means to achieve freedom, and freedom and achievement.

5. "Given her personal characteristics, social background, economic circumstances and so on, a person has the ability to do (or be) certain things that she has reason to value. The reason for valuation can be direct (the functioning involved may directly enrich her life, such as being wellnourished or being healthy), or indirect (the functioning involved may contribute to further production, or command a price in the market)" (Sen 2000: 293).

6. "Identifying the value of the capability set with the value of the chosen functioning combination permits the capability approach to put as much weight - including possibly all the weight - on actual achievements" (Sen 2009: 236).

7. Sen (1990b) and Nussbaum (2000) pay attention to the social norms and traditions that form women's preferences and influence their aspirations and effective choices. Sen refers, as examples, to ancestral practices such as the genital mutilation of young women or the punishment of adulterous women.

8. Also, James' concept of a social self as constituent of the self would be useful here useful if we are to identify some analogies between Sen's and pragmatists' ideas. However, a full discussion of James' psychology is beyond the scope of this paper.

9. See on this point, among others, Sharma \& Sharma 2010; and Max-Neef \& Ekins 1992.

10. "Behavioral codes vary even among the developed capitalist economies, and so does their effectiveness in promoting economic performance. While capitalism has been very successful in radically enhancing output and raising productivity in the modern world, it is still the case that the experiences of different countries are quite diverse" (Sen 2000: 265).

11. One may say that Deneulin and McGregor have as target Ingrid Robeyns's indication of the capability approach as an ethical individualism, namely that only individuals are the units of moral concern - and social affairs are evaluated for their direct and indirect effects on individuals (Deneulin \& McGregor 2009: 17). However, Deneulin and McGregor explicitly refer also to Sen and to the capability approach as "advanced by Sen." In another point of their paper they argue that the capability approach "as enunciated by Sen is deliberately and fundamentally incomplete" for "his development of the approach focuses more on the challenges of freedom than on the challenges of living together" (Deneulin \& McGregor 2009: 10). One, thence, may also suppose that their target is Sen's arguments and only indirectly Robeyen's interpretation of them. 
12. As is known, since the 1980s a partnership between economics and psychology (in particular, cognitive psychology) has offered some interesting insights on human preferences, behaviors, and the hedonistic dimension of choices, showing that people often do not choose what they really want and do not have consistent preferences since they do not know how to maximize them (Kahneman et al. 1997; Kahneman 2011).

13. Zimmermann (2006) has shown the potential of the connections between CA and Pragmatism for a qualitative method of inquiry into sociological issues that draws on a pragmatist and configurational approach. For a more general perspective against the dichotomy between normative and social inquiry, see Frega 2014.

14. It is noteworthy that Mead's criticism of the psychological presuppositions of the economic science is consonant with Thorstein Veblen's critique of neoclassical economic theories (Veblen 1899a, 1899b, 1900 and 1909), as well as Dewey's critique of marginal utility (see Tilman \& Knapp 1999). Baggio (2016a) sketches some considerations of Veblen's implicit and explicit references to pragmatism and functional psychology in Veblen's writings on evolutionary economics from the years 1896-1900, when he was at the University of Chicago with Dewey and Mead.

15. It is worth noting that, nowadays, the "physiological fringes" involved in "unconscious communication" are explained by neural systems involved in the genesis of emotional sequences in action in the performance of specific acts. Panksepp has recently indicated eight neuronal systems that express, among others, interpersonal emotional systems of attachment, care-giving, the competitive interaction, and joint cooperation. These systems express the innate social dimension of bodies and form the basis of the most advanced forms of human social interaction (see Panksepp 1998; and Liotti 2005). It is just to note that we are not speaking of an anachronistic theory of the origin of human communication. Baldwin highlights the fact that many of Mead's studies have anticipated the modern analysis of social behaviorism on emotions. In particular, there are many aspects present in the writings of Mead which have been empirically verified during the second half of the 20th century (Baldwin 1992). For further reading on this point, see Baggio 2016c.

16. Some insights on Mead's bio-social theory of the Self and pragmatist basis of neuroeconomics are developed in Baggio 2016b. Here a parallel between Mead's bio-social theory of mind and the Self and the cognitive sciences are sketched with the aim of shedding light on some topical economic issues.

17. An interesting insight into the cognitive and affective dimensions of Smith's notion of sympathy is elaborated in Bréban 2015.

18. "In acquiring one's conception of the world one always belongs to a particular grouping which is that of all the social elements which share the same mode of thinking and acting. We are all conformists of some conformism or other, always man in the mass or collective man" (Gramsci 1975: 324).

19. "It is in the form of the generalized other that the social process influences the behavior of the individuals involved in it and carrying it on, i.e., that the community exercises control over the conduct of its individual members; for it is in this form that the social process or community enters as a determining factor into the individual's thinking” (Mead 1934: 155).

20. On this point, see Klamer 2003. According to Sen, non-commensurability "is present when several dimensions of value are irreducible to one another" (Sen 2009: 240).

21. Putnam points out that norms of reciprocity are generally good for those inside the community, but the external effects of social capital are not always positive. A social group may exploit social capital "to achieve ends that are antisocial from a wider perspective" (Putnam 2000: 19). On this point, Mead would have argued that even social situations involving complex social antagonisms and diversities of social interests, and lacking the unifying influence of common social ends and motives, are "definite aspects of or ingredients in the general relational pattern of that process as a whole" (Mead 1934: 323). They are therefore aspects of a potentially 
enlarged "social capital." According to Mead, "an organization of common attitudes which shall be found in all individuals" can help to implement positive external effects (Mead 1934: 323). This means making individuals "more aware of the collective significance of the myriad minute decisions that we make daily to invest - or disinvest - in social capital" (Putnam 2000: 439).

22. On this point, it is useful to refer to the ethical reflections of Mead's colleague and friend John Dewey, who argues that: "both self-love and altruism are acquired dispositions, not original ingredients in our psychological make-up, and that each of them may be either morally good or morally reprehensible. Psychologically speaking, our native impulses and acts are neither egoistic nor altruistic; that is, they are not actuated by conscious regard for either one's own food or that of others. They are rather direct responses to situations" (Dewey \& Tufts 1932: 324).

23. "Since the prevailing individualism was expressed in an economic theory and practice which taught that each man was actuated by an exclusive regard for his own profit, moralists were led to insist upon the need of some check upon this ruthless individualism, and to accentuate the supremacy in morals (as distinct from business) of sympathy and benevolent regard for others. The other significance of this appeal is, however, to make us realize the fact that regard for self and regard for others are both of them secondary phases of a more normal and complete interest: regard for the welfare and integrity of the social groups of which we form a part" (Dewey \& Tufts 1932: 331-2).

24. One of the main consequences of this approach would be that, since agency roles concern an individual's evaluation of motives which would be different from personal preferences, the mixture of motivations makes it hard to gain insight into their well-being on the basis of the observation of behavior (Sen 1985: 188). Whilst behavior may correspond to some constants interpreted as preferences, the causal connection almost never could be inferred to be as straightforward as it a theory of revealed preferences assumes. To identify a pattern of behavior does not explain it. The rejection of the epistemic value of introspection and communication and simplification of the relationship between preference and behavior underestimate the role subjective elements and ethical rules specific to a certain social context play in decision-making. On the contrary, the new framework helps to rehabilitate the epistemic value of introspection and a richer multi-level approach to the analysis of people's economic behavior. On this point see Baggio 2016c.

\section{ABSTRACTS}

The paper seeks to show the potentialities of a wider perspective concerning human economic behavior and decision-making processes intertwining Mead's and Sen's ideas on self-identity and social context. Emerging developments of my findings strengthen, at once, the principled commitment to freedom of choice, revealing from a "Mead-Sen" perspective the instrumental role of social behavioral patterns and socio-cultural environment (social group, community, nationality, race, sex, and now social media) in the orientation of persons' (economic) behaviors. In particular, a Mead-Sen approach would help clarify how people develop their attitudes and dispositions to think and behave, namely examining the habits at the basis of everyday processes of evaluation and choice as manifestations of practical judgment. 
AUTHOR

GUIDO BAGGIO

Università degli Studi Roma Tre

guido.baggio[at]uniroma3.it 